National and Global Petroleum Assessment

\title{
Assessment of Undiscovered Continuous Gas Resources of the Ordos Basin Province, China, 2015
}

Using a geology-based assessment methodology, the U.S. Geological Survey estimated mean resources of 28 trillion cubic feet of tight gas and 5.6 trillion cubic feet of coalbed gas in upper Paleozoic rocks in the Ordos Basin Province, China.

\section{Introduction}

The U.S. Geological Survey quantitatively assessed the potential for technically recoverable resources of continuous (unconventional) natural gas in the Ordos Basin Province of China as part of the assessment of priority basins worldwide. Large volumes of tight gas and coalbed gas have been discovered and produced from upper Paleozoic rocks of the Ordos Basin Province. Data on the number of wells and well productivity are, however, publicly unavailable. Limited access to data contributed to the large uncertainty in the resource estimates.

The assessments were completed using a methodology developed by the U.S. Geological Survey. This methodology uses Monte Carlo simulation to calculate resource volumes based on probabilistic estimates of assessment unit (AU) area, average well drainage area, percent of AU area that is untested, well success ratio, average estimated ultimate recovery per well, and average coproduct ratios (Charpentier and Cook, 2010). Inadequate data pertaining to the numbers of wells and well productivity in the Ordos Basin Province required that these input distributions be based on the range of behavior in the complete set of analog tight gas and coalbed gas plays that have been assessed in the United States.

Two AUs were defined using published geologic studies and the IHS Energy (2014) database. The Upper Paleozoic Tight Gas AU covers 147,409 square kilometers of the central part of the Ordos Basin Province that gently dips (less than 1 degree) to the west (fig. 1). The western and southern boundaries of the AU are defined by fault zones. The northern boundary is defined as the transition between the gas-water zone and the updip water zone (Xiao and others, 2005). The eastern boundary, which separates the tight gas AU from the Upper Paleozoic Coalbed Gas AU, is the $-1,200$ meter subsurface depth contour. The sources of the gas are the coal beds in the Taiyuan and Shanxi Formations. Reservoirs are mainly low-permeability sandstones, especially in the Shanxi and lower Shihezi Formations. The accumulation is a basin-center, gas-charged zone with an updip water leg. Future potential is envisioned as extending into facies with poorer porosity and permeability than what is being currently developed.
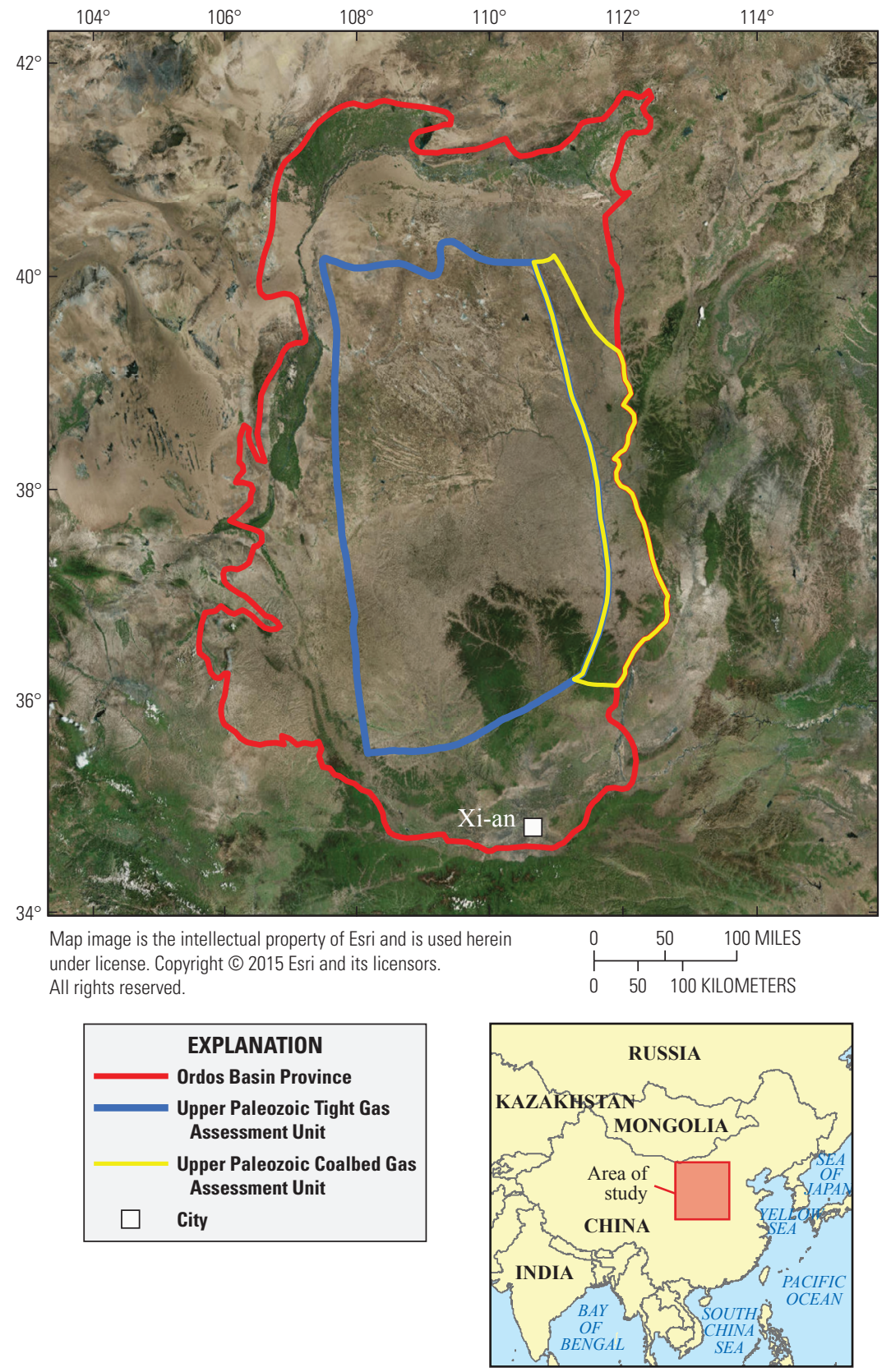

Figure 1. Map showing the extent of the Ordos Basin Province, China, and the two assessments units defined in this study. 
The Upper Paleozoic Coalbed Gas AU covers 24,410 square kilometers of the eastern part of the Ordos Basin Province (fig. 1). The eastern boundary of the AU is the basin structural boundary. The northern boundary is defined as the transition from the gas and water zone to the updip water zone (Xiao and others, 2005), which corresponds to the 0.8 percent coal vitrinite reflectance contour. The southern boundary is the 5 -meter net-coal isopach. The western boundary, which separates the coalbed gas AU from the tight gas AU, is the $-1,200$ meter subsurface depth contour. The coals in the Taiyuan and Shanxi Formations are both the source of the gas and the reservoir.

The assessment input data for the two AUs are summarized in table 1.

Table 1. Key assessment input data for the two continuous assessment units in the Ordos Basin Province, China.

[AU, assessment unit; \%, percent; EUR, estimated ultimate recovery per well; BCFG, billion cubic feet of gas. The EUR, well drainage area, and success ratios are taken from U.S. shale-gas analogs. The average EUR input is the minimum, median, and calculated mean. Shading indicates not applicable]

\begin{tabular}{|l|r|r|r|r|r|r|r|r|}
\hline \multirow{2}{*}{ Assessment input data } & \multicolumn{4}{|c|}{ Upper Paleozoic Tight Gas } & \multicolumn{3}{c|}{ Upper Paleozoic Coalbed Gas } \\
\cline { 2 - 10 } & Minimum & \multicolumn{1}{c|}{ Mode } & Maximum & $\begin{array}{c}\text { Calculated } \\
\text { mean }\end{array}$ & Minimum & Mode & $\begin{array}{c}\text { Maximum } \\
\text { Calculated } \\
\text { mean }\end{array}$ \\
\hline $\begin{array}{l}\text { Potential production area of AU } \\
\text { (acres) }\end{array}$ & $6,200,000$ & $12,400,000$ & $18,200,000$ & $12,266,667$ & $2,000,000$ & $3,000,000$ & $5,000,000$ & $3,333,333$ \\
\hline $\begin{array}{l}\text { Average drainage area of wells } \\
\text { (acres) }\end{array}$ & 100 & 120 & 200 & 140 & 70 & 100 & 160 & 110 \\
\hline$\%$ area untested in AU & 77 & 92 & 96 & 88 & 94 & 99 & 100 & 98 \\
\hline Success ratios (\%) & 30 & 50 & 90 & 57 & 25 & 50 & 95 & 57 \\
\hline Average EUR (BCFG) & 0.2 & 0.6 & 1.4 & 0.637 & 0.1 & 0.3 & 1.0 & 0.337 \\
\hline AU probability & 1.0 & & & & 1.0 & & & \\
\hline
\end{tabular}

Table 2. Assessment results for continuous gas resources in Ordos Basin Province, China.

[AU, assessment unit; BCFG, billion cubic feet of gas; NGL, natural gas liquids; MMBNGL, million barrels of natural gas liquids. Results shown are fully risked estimates. For gas accumulations, all liquids are included under the NGL category. F95 represents a 95 percent chance of at least the amount tabulated. Other fractiles are defined similarly. Fractiles are additive under assumption of perfect positve correlation. Shading indicates not applicable]

\begin{tabular}{|c|c|c|c|c|c|c|c|c|c|c|}
\hline \multirow{3}{*}{ Total petroleum system and AU } & \multirow{3}{*}{$\begin{array}{c}\text { AU } \\
\text { probability }\end{array}$} & \multirow{3}{*}{$\begin{array}{l}\text { Accumulation } \\
\text { type }\end{array}$} & \multicolumn{8}{|c|}{ Total undiscovered resources } \\
\hline & & & \multicolumn{4}{|c|}{ Gas (BCFG) } & \multicolumn{4}{|c|}{ NGL (MMBNGL) } \\
\hline & & & F95 & F50 & F5 & Mean & F95 & F50 & F5 & Mean \\
\hline \multicolumn{11}{|c|}{ Paleozoic Composite Total Petroleum System } \\
\hline Upper Paleozoic Tight Gas AU & 1.0 & Gas & 13,172 & 25,831 & 50,005 & 27,964 & 25 & 60 & 147 & 70 \\
\hline Upper Paleozoic Coalbed Gas AU & 1.0 & Gas & 2,302 & 4,960 & 11,311 & 5,622 & 0 & 0 & 0 & 0 \\
\hline Total undiscovered unconventional resources & & & 15,474 & 30,791 & 61,316 & 33,586 & 25 & 60 & 147 & 70 \\
\hline
\end{tabular}

\section{Resource Summary}

Resource estimates are summarized in table 2. The mean resource estimates for the Upper Paleozoic Tight Gas AU are 27,964 billion cubic feet of gas (BCFG), with a F95 to F5 fractile range from 13,172 to $50,005 \mathrm{BCFG}$, respectively and 70 million barrels of natural gas liquids (MMBNGL), with a F95 to F5 fractile range from 25 to $147 \mathrm{MMBNGL}$, respectively. The mean resource estimate for the Upper Paleozoic Coalbed Gas AU is 5,622 BCFG, with a F95 to F5 fractile range from 2,302 to 11,311 BCFG, respectively. The mean estimate of the number of wells that would be required to develop the resources in the tight gas and coalbed gas AUs are 44,880 and 17,258 wells, respectively.

\section{References Cited}

Charpentier, R.R., and Cook, T.A., 2010, Improved USGS methodology for assessing continuous petroleum resources: U.S. Geological Survey Data Series 547, 22 p. and model program, accessed November 5, 2015, at http://pubs.usgs.gov/ds/547/.
IHS Energy, 2014, International petroleum exploration and production database: Englewood, Colo., IHS Energy.

Xiao, X.M., Zhao, B.Q., Thu, Z.L., Song, Z.G., and Wilkins, R.W.T., 2005, Upper Paleozoic petroleum system, Ordos Basin, China: Marine and Petroleum Geology, v. 22, p. 945-963.

\section{Ordos Basin Assessment Team}

Ronald R. Charpentier, Timothy R. Klett, Christopher J. Schenk, Michael E. Brownfield, Stephanie B. Gaswirth, Phuong A. Le, Heidi M. Leathers-Miller, Kristen R. Marra, and Tracey J. Mercier.

\section{For Further Information}

Assessment results are available at the U.S. Geological Survey Energy Program Web site at http://energy.usgs.gov/OilGas/. 